\title{
Demasiadamente humano: um olhar sobre War Before Civilization, de Lawrence $\mathrm{H}$. Keeley
}

Flávio Pedroso Mendes ${ }^{1}$

A guerra, ou o intercurso político pela força, mesmo não sendo a regra nos relacionamentos interestatais, é uma possibilidade sempre presente e terrivelmente recorrente. Isso torna a política internacional um dos campos cujas atividades se dão à sombra de algo que é, espacial e temporalmente, uma 'exceção'. Entretanto, quando a 'exceção' é uma constante potencial com corolários dramáticos para o destino de sociedades inteiras, não é de surpreender que isso se dê. Essa trágica realidade das relações internacionais é tornada possível pelo fato de não haver nada, para além das próprias dinâmicas políticas - balanceamento de poder e barganha -, que impeça que um lado recorra à força para obrigar outro a fazer a sua vontade. Mas terá a guerra surgido como instrumento político a partir de algum desenvolvimento histórico, algum marco tecnológico ou organizacional das sociedades humanas? Ou será a guerra intrínseca aos relacionamentos humanos desde nossa constituição como espécie? É com o propósito de responder a essas perguntas que Lawrence $\mathrm{H}$. Keeley escreveu o seu War Before Civilization, publicado em 1996. Trata-se de um trabalho ambicioso que margeia os Estudos Estratégicos, a História, a Ciência Política e a Antropologia, com lições que convidam a repensar não só os milênios de (pré-)história humana, mas também os dilemas e desafios colocados às sociedades contemporâneas. $\mathrm{A}$ relevância da obra de Keeley, somada à sua pouca difusão no meio acadêmico brasileiro, deram o impulso à formulação deste ensaio de revisão.

$\mathrm{O}$ estudo da guerra em sociedades primitivas encontra imediatamente um problema: menos de $0,05 \%$ da história humana está retratado por escrito. Para Keeley, os arqueólogos e antropólogos, profissionais que possuem as ferramentas para decifrar o passado desconhecido e para conhecer

\footnotetext{
1 Professor do curso de Relações Internacionais da Universidade Federal de Uberlândia, é mestre em Estudos Estratégicos pela Coppe/UFRJ e doutorando em Relações Internacionais pela USP.
} 
efetivamente a realidade de sociedades que ainda vivem em estágio primitivo, têm feito, no máximo, muito pouco para entender a guerra na pré-história e entre povos atuais afastados da civilização. Essa negligência foi responsável pela popularização de mitos sobre as formas de vida primitivas, cujos extremos retratam as noções de "progresso humano" e de "passado beato", que encontram nas discussões de Hobbes e Rousseau as melhores construções na modernidade.

A etnografia do séc. $X X$, com o desenvolvimento do método da observação participativa, fez crescer a crença de que a guerra, quando praticada por sociedades primitivas, não eram (são) empreendimentos sérios, arriscados e temerários como as guerras travadas por sociedades civilizadas. Haveria ali uma diferença expressiva e qualitativa, tanto nos meios quanto nas motivações. Guerras primitivas seriam menos racionais, mais motivadas por fatores pessoais e psicológicos e seriam, portanto, uma matéria menos séria e decisiva para os rumos dos povos que as travavam.

Para Keeley, o resultado foi a transposição de um vago preconceito para um status quase teórico que apresentava as sociedades primitivas e préhistóricas como particularmente pacíficas e que ignoravam a guerra como uma atividade política e social importante. $\mathrm{O}$ autor busca contestar com veemência essa tese, em duas direções: primeiro, demonstrando como as abordagens de pacificação do passado sistematicamente negligenciam fortes evidências, em sua maioria arqueológicas, que apontam para uma realidade significativamente mais bruta e truculenta; segundo, avaliando os méritos das guerras primitivas em seus próprios termos, ou seja, em termos de sua intensidade, de sua efetividade e de seu risco relativo. Em outras palavras, Keeley pretende demonstrar que as conclusões anteriores se devem a julgamentos estéticos de forma e estilo e não condizem com a observação séria e sistemática do fenômeno.

Mediante observação de uma série de estudos arqueológicos que abarcam grandes porções do planeta, e munido de um espectro que contempla as sociedades humanas em diferentes níveis de organização e complexidade (desde bandos até os Estados modernos), Keeley deriva algumas conclusões fundamentais: (i) a guerra é uma prática universalmente comum e usual, independentemente do nível de complexidade das sociedades; (ii) a frequência 
Mendes, Flávio Pedroso. Demasiadamente humano: um olhar sobre War Before Civilization, de Lawrence H. Keeley

com que povos primitivos lutam uns com os outros é significativamente maior que a verificada inclusive entre as sociedades civilizadas mais belicosas (romanos); (iii) mesmo com o alto grau de mobilização das sociedades contemporâneas, particularmente a partir da introdução do alistamento obrigatório, povos primitivos tendem a organizar um percentual ainda maior de seus homens adultos para atividades combatentes (Keeley, 1996, pp. 27-39).

Quanto à condução das guerras primitivas, a principal linha argumentativa dos antropólogos pacifistas avança que o combate se dá de forma ritualizada, conscientemente moderada e projetada para minimizar danos, resultando em pouca efetividade tática. Tratar-se-ia, em outras palavras, não de luta para a imposição de uma vontade, mas de uma manifestação de elementos sociais e culturais mais amplos². A ineficiência seria a principal característica das guerras primitivas, resumida por uma série de fatores identificados por Keeley nas principais argumentações:

i. Participação voluntária, resultando em baixa capacidade de mobilização;

ii. Precário nexo logístico;

iii. Impossibilidade de condução de longas campanhas (diante de i e de ii);

iv. Ausência de treinamento e de organização das forças como unidades;

v. Baixa capacidade de comando e controle;

vi. Disciplina e moral fracos;

vii. Baixa especialização de armamentos e ignorância da arte de construir fortificações;

viii. Inexistência de especialização em formas de luta (armas);

ix. Ineficácia tática e falta de conhecimento de princípios básicos da estratégia (Keeley, 1996, p. 11).

Keeley, a partir de uma avaliação dos aspectos mais gerais de organização política e sócio-econômica das sociedades primitivas, acredita que

\footnotetext{
${ }^{2} \mathrm{O}$ representante contemporâneo mais destacado dessa corrente é Keegan (2006), que elaborou uma pseudoteoria da guerra como fenômeno cultural.
} 
todas as supostas deficiências táticas, estratégicas e logísticas são função direta do tipo de autoridade dos líderes, de uma estrutura social igualitária, de baixo excedente produtivo e de menor densidade populacional ${ }^{3}$. Assim, não se trata de reconhecer somente que é assim que sociedades primitivas lutam, mas também que é assim que elas vivem. Qualquer sociedade possui limites colocados por sua demografia, economia e sistema social, e não há por que esperar que isso seja diferente nas sociedades primitivas. Aqui, Keeley clama razoavelmente por um olhar proporcional e relativista sobre os esforços realizados na guerra diante do que uma sociedade primitiva, tendo em vista sua organização política e sócio-econômica, é capaz de produzir e de oferecer.

Keeley propõe ainda uma tipologia que apresenta gradativamente os níveis de intensidade dos combates travados por sociedades primitivas (Keeley, 1996, pp. 59-69). Com o menor nível de intensidade figuram as emboscadas, a forma mais frequente e utilizada, em que pequenos grupos de indivíduos furtivamente invadem o território de grupos rivais, causando algumas vítimas e pilhando parte de seus recursos. Os danos individuais relativamente pequenos seriam compensados pela alta frequência dessa prática, que cumulativamente poderia gerar uma corrosão insuperável a uma população diminuta. No nível mais extremo de violência estão os massacres, ataquessurpresas articulados e em grande escala, cujo propósito é aniquilar por completo uma população rival. Apesar de raros, os massacres eram possibilidades sempre presentes e que atestam o potencial destrutivo das guerras primitivas.

Em um dos pontos mais contra-intuitivos do argumento, o autor afirma que dificilmente os choques das formas de luta dos civilizados e dos primitivos podem atestar a superioridade decisiva dos primeiros sobre os segundos. Partindo de exemplos como os encontros entre romanos e povos celtas e germânicos, entre os brancos e nativos norte-americanos e entre europeus e colonos africanos, Keeley acredita haver ampla evidência de que as formas e instrumentos civilizados de combate se mostravam muitas vezes incapazes de subjugar povos primitivos, devendo os colonizadores recorrer a aliados locais

3 O argumento histórico sobre a importância da densidade populacional para a organização e especialização das primeiras sociedades humanas é cuidadosamente construído e demonstrado em Diamond (2006). 
Mendes, Flávio Pedroso. Demasiadamente humano: um olhar sobre War Before Civilization, de Lawrence H. Keeley

primitivos, adotar eles mesmos formas de luta primitivas ou, em última instância, prevalecer devido à sua maior capacidade econômico-produtiva e aos seus nexos de transporte e logísticos mais elaborados ${ }^{4}$ (Keeley, 1996, pp. 71-81). Numa passagem curiosa e certamente controversa, Keeley afirma:

\footnotetext{
Mas ao mesmo tempo em que é verdade que a civilização europeia se estendeu firme e dramaticamente até os últimos confins da terra durante os quatro séculos passados, não é de modo algum claro que essa expansão é consequencia de armamentos superiores ou de técnicas militares especializadas (Keeley, 1996, p. 71; tradução nossa).
}

O problema da eficiência, como aludido anteriormente, para Keeley só pode ser julgado em termos relativos, contrastando resultados com esforços empregados. Em análise comparativa, o autor conclui que o número proporcional de baixas e o grau de deterioração social em guerras primitivas são expressivamente mais elevados do que em guerras civilizadas, o que pode ser atribuído a: (i) grande frequência da ocorrência de guerras; (ii) grande proporção de indivíduos engajados em atividades combatentes; (iii) prática de massacres totais, porém raros; (iv) aniquilação de prisioneiros; (v) e atrocidades cometidas contra crianças e mulheres de povos vencidos (Keeley, 1996, pp. 83-97).

Um dos argumentos centrais que afirmam haver uma diferenciação qualitativa entre guerras primitivas e civilizadas avança que os motivos que levam povos primitivos à guerra são de maior imaterialidade e frivolidade, se comparados às causas das 'guerras civilizadas', e que nascem de estímulos psicológicos e irracionais. Keeley contesta, apontando inicialmente a indistinção dos efeitos materiais da condução mesma das guerras primitivas e civilizadas: em ambos os casos, há a tendência à pilhagem e à apropriação de bens dos vencidos. Ademais, para o autor há ampla evidência de variação espacial entre tribos que ocupam ou ocupavam uma dada região, sugerindo um status territorial para suas confrontações, análogo ao das conquistas imperialistas europeias e no oeste dos EUA. Guerras aparentemente motivadas pela criação de uma zona tampão (buffer zones) entre sociedades distintas parecem ser também empreendimentos comuns (Keeley, 1996, pp. 99-112).

\footnotetext{
${ }^{4}$ É pertinente mais uma vez citar a importância da discussão de Diamond (2006), que demonstra como o contato prematuro com doenças epidêmicas constituiu uma vantagem decisiva dos europeus sobre os povos colonizados, particularmente nas Américas. A esse respeito, ver também Mcneill (1976).
} 
Entretanto, Keeley sugere grande reserva e precaução no estabelecimento de causas isoladas para as guerras: "se as guerras civilizadas possuem uma multiplicidade de causas e motivos ambíguos, por que presumir que guerras em sociedades tribais, em que não há governo centralizado ou registros volumosos, podem precisamente ser reduzidas a um motivo único e incontroverso?" (Keeley, 1996, p. 114). Para Keeley, a única motivação que parece estar definitivamente fora do escopo de guerras tribais é a de subjugar e explorar populações rivais, por ausência de mecanismos institucionais e administrativos que permitam a dominação hegemônica e a extração de tributos. Afora isso, benefícios materiais e econômicos essencialmente similares aparecem igualmente no escopo de guerras primitivas e civilizadas.

A investigação não aponta nenhuma correlação decisiva entre densidade populacional e propensão à ocorrência de guerras entre sociedades primitivas, contrariando uma noção altamente intuitiva; porém uma constatação, desta vez contra-intuitiva, brota da análise dos dados: povos primitivos tendem a ir à guerra com mais frequência justamente com seus parceiros mais estreitos de troca e intercâmbio. (Keeley, 1996, pp. 121-126). Esse poderoso golpe contra a perspectiva da paz democrática/liberal ${ }^{5}$ pode ser tentativamente explicado por diversas razões, entre as quais a maior probabilidade de ocorrência de atritos e crises com a maior intensidade e frequência dos contatos e a natural propensão a tomar aquilo que não se tem, mas que se valoriza, atributos logicamente encontrados em objetos de trocas comerciais.

Com relação a elementos conjunturais com potencial influência sobre a propensão à ocorrência de guerras entre sociedades primitivas, Keeley reconhece a presença de grupos particularmente agressivos - quaisquer que sejam as causas dessa especial agressividade - como algo que exerce uma forte pressão para que os demais estejam sempre preparados e dispostos a fazer a guerra. Aqui, tem-se uma analogia clara com o mundo desenhado por Hobbes e expressado pela passagem do realismo político, que apregoa que, num tal contexto, o estabelecimento unilateral da paz equivale a cometer suicídio $^{6}$. Keeley ainda arregimenta evidências que derrubam outra crença

\footnotetext{
${ }^{5}$ Para uma apresentação mais recente e articulada dessa perspectiva, ver Oneal e Russet (2001).

${ }^{6}$ A elaboração recente mais consistente do argumento se encontra em Mearsheimer (2001).
} 
Mendes, Flávio Pedroso. Demasiadamente humano: um olhar sobre War Before Civilization, de Lawrence H. Keeley

largamente avançada por antropólogos, a saber, de que regiões fronteiriças entre unidades étnicas e sócio-econômicas distintas seriam particularmente pacíficas. Três variáveis parecem contribuir para o contrário: (i) a já mencionada propensão ao conflito entre parceiros de trocas; (ii) a inexistência de laços culturais e sociais mais fortes para produzir a resolução pacíficas de controvérsias; (iii) e a exposição direta a incursões e pilhagem (Keeley, 1996, pp. 130-139). As condições para a guerra também parecem mudar em função de desastres naturais que causem grande provação, em que a lógica da sobrevivência passa a ditar com ainda mais força as necessidades.

Para Keeley, o fato de a belicosidade ser a norma, não a exceção, mesmo entre sociedades tão distintas, não significa que a violência esteja impressa indelevelmente na natureza humana. Ao contrário, o autor apresenta argumentos fortes de que a guerra é pelo menos tão depreciada entre tribos primitivas quanto entre cidadãos modernos. A explicação da aparente insuperabilidade de uma situação que é, não obstante, condenada, Keeley parece encontrar em parte no nível estrutural: "a paz é inevitavelmente rara onde não há uma instituição com autoridade moral e poder físico para mantê-la [...]" (Keeley, 1996, p. 161). O autor identifica também uma natural relação custo-benefício, donde resulta concebivelmente que uma determinada paz pode ser muito custosa para ser mantida. Entretanto, algumas lições gerais são derivadas da investigação e podem, para Keeley, influenciar a propensão ao conflito: (i) a existência de isolamento geográfico; (ii) o peso amargo e doloroso de uma derrota devastadora; (iii) a presença de um efetivo terceiro ator com capacidade de mediação; (iv) algum nível de respeito e compartilhamento de valores e costumes; (v) e esforços para evitar o monopólio da produção de bens que outras sociedades julguem essenciais (Keeley, 1996, pp. 143-161).

Em suma, Keeley acredita ter demonstrado que arqueólogos e antropólogos do séc. XX derivaram conclusões sobre guerra e paz entre sociedades primitivas em direção claramente contrária às evidências. Explicar o porquê dessa discrepância não é apenas curioso, mas se apresenta como um imperativo intelectual para o tratamento dos dilemas da produção de conhecimento no futuro. Aparentemente não se tratou de pura desonestidade,

${ }^{7} \mathrm{O}$ argumento estrutural encontra sua mais sólida e influente construção na teoria das relações internacionais em Waltz (1979). 
mas da múltipla influência de fenômenos e tendências que transcendiam à academia e à construção do saber, tais como os horrores das duas guerras mundiais, culminando na detonação de artefatos nucleares; o fim do imperialismo e do seu imperativo moral; o desaparecimento (e consequente afastamento) da figura do primitivo; e a perda de fé no progresso (Keeley, 1996, pp. 163-171). Mas Keeley julga que a ciência, contudo, quando plenamente desenvolvida, deve ter mecanismos próprios para proteger-se, na medida do possível, contra esse tipo de externalidade:

\footnotetext{
Como é verdade com respeito às ideias em todos os lugares, o entendimento científico está normalmente enraizado em valores e atitudes de uma era e de uma cultura particular. O que salva as proposições científicas de serem apenas modismo intelectual é sua habilidade de se submeter a testes contra evidências críticas (Keeley, 1996: 170; tradução nossa).
}

Keeley conclui inequivocamente que guerras primitivas são guerras em sua essência, não menos importantes e decisivas para o futuro das sociedades envolvidas. É uma pena, contudo, que a essa importante e fundamentada conclusão tenha se seguido uma injustiça descomunal. Ao atestar a insuficiência de tratamentos anteriores do fenômeno da guerra, supostamente incapazes de dar conta de que a guerra envolve sociedades em sua completude, não apenas forças combatentes no teatro de operações, Keeley inclui Clausewitz como um dos teóricos que contribuíram para o entendimento incompleto e 'militarista' do fenômeno. No entanto, foi o próprio Clausewitz (1993) que incorporou cientificamente na sua teoria da guerra o elemento 'povo', ao lado das forças armadas e seu comandante e da liderança política, como um dos elementos da "trindade esquisita" que compõe essencialmente $o$ fenômeno da guerra. À parte disso, não obstante, e talvez sem que o próprio autor a reconheça plenamente, uma das contribuições mais importantes de Keeley, como se acredita ter ficado claro, foi justamente demonstrar a tese clausewitziana fundamental de que a guerra, em qualquer tempo e lugar, é uma manifestação integralmente política.

\footnotetext{
${ }^{8}$ Tradução proposta e justificada em Diniz (2002).
} 
Mendes, Flávio Pedroso. Demasiadamente humano: um olhar sobre War Before Civilization, de Lawrence H. Keeley

\section{Referências Bibliográficas}

Clausewitz, Carl von. (1993) On War. New York: Alfred A. Knopf.

Diamond, Jared. (2006) Armas, Germes e Aço: os Destinos das Sociedades Humanas. Rio de janeiro: Record.

Diniz, Eugenio. (2002). Clausewitz, o Balanço Ataque-Defesa e a Teoria das Relações Internacionais. (Tese de Doutorado) Rio de Janeiro: PEP/COPPE/UFRJ. Mimeo.

Keegan, John. (2006). Uma História da Guerra. São Paulo: Companhia das Letras.

Keeley, Lawrence H. (1996) War Before Civilization. New York: Oxford University Press.

Mcneill, William. (1976) Plagues and Peoples. New York: Anchor Books.

Mearsheimer, John J. (2001) The Tragedy of Great Powers Politics. New York: Norton \& Company.

Oneal, John; Russet, Bruce. (2001). Triagulating Peace - Democracy, Interdependence and International organizations. New York: Norton \& Company.

Waltz, Kenneth N. (1979) Theory of International Politics. New York: McGraw-Hill. 